\title{
Flora do Ceará, Brasil: Oxalidaceae
}

\author{
Flora of Ceará state, Brazil: Oxalidaceae
}

\author{
Maria Iracema Bezerra Loiola ${ }^{1,4}$, Rayane de Tasso Moreira Ribeiro ${ }^{2}$, Francisco Átila Magalhães Leles ${ }^{1}$, \\ Francisco Romário Silva Tabosa ${ }^{1} \&$ Maria Carolina de Abreu $^{3}$
}

\begin{abstract}
Resumo
Esse estudo objetivou o registro e a atualização da distribuição geográfica das espécies de Oxalidaceae no estado do Ceará, dando continuidade ao "Projeto Flora do Ceará". Para as análises morfológicas, descrições e elaboração do mapa de distribuição foram consultadas coleções de herbários (ASE, EAC, HUEFS, RB, UFRN) e amostras obtidas em expedições de campo realizadas no período de março/2012 a abril/2015. As identificações foram baseadas em coleções-tipos e literatura especializada. Para o Ceará foram registradas 14 espécies de Oxalis. As principais características usadas para a identificação das espécies foram tipo de folha, forma dos folíolos e cor das flores. Oxalis divaricata foi registrada em todos os tipos de vegetação do estado; $O$. cratensis, $O$. frutescens, $O$. glaucescens e $O$. juruensis var. juruensis na floresta ombrófila densa, floresta estacional semidecidual e savana estépica (carrasco) e as demais espécies ocorreram preferencialmente na floresta ombrófila densa. Sete espécies foram registradas em Unidades de Conservação do estado.

Palavras-chave: distribuição, neotrópicos, Oxalis, taxonomia.
\end{abstract}

\begin{abstract}
This study aimed to carry out the floristic inventory and update the geographical distribution of Oxalidaceae species that occur in Ceará state, continuing the project "Flora do Ceará". Herbaria specimens (ASE, EAC, HUEFS, RB, UFRN) and material obtained during field expeditions, from march/2012 to april/2015, were used to perform the morphological analyses, species' descriptions and distribution maps. The identifications were based on type collections and specific literature. For Ceará, fourteen species of Oxalis were recorded. The main features used to identify the species were the type of leaf, shape of leaflets and color of the flowers. Oxalis divaricata was registered in all vegetation types; O. cratensis, O. frutescens, O. glaucescens and O. juruensis var. juruensis in ombrophilous dense forest, seasonal semideciduous forest (known as "mata seca'), and stepic savannah (locally known as "carrasco") and the other species occurred preferentially in ombrophilous dense forest. Seven species were recorded in state Protected Areas.
\end{abstract}

Key words: distribution, neotropics, Oxalis, taxonomy.

\section{Introdução}

Oxalidaceae R. Br. é composta por cinco gêneros e aproximadamente 770 espécies com ampla distribuição nas regiões tropicais e subtropicais em todo o planeta (Stevens 2001; Cocucci 2004). A América do Sul e África austral são os principais centros de diversidade desta família (Eiten 1963; Lourteig 1980; Oberlander et al. 2011).
Seus representantes apresentam hábito variando desde ervas a subarbustos com caules aéreos ou subterrâneos, ou raramente arbustos ou árvores; folhas alternas, subopostas ou pseudoverticiladas, tri a plurifolioladas, pinadas ou digitadas, raro unifolioladas, com ou sem estípulas; flores solitárias ou em inflorescências do tipo umbela ou cimeira; flores actinomorfas, diclamídeas, bissexuais, pentâmeras; estames 10,

\footnotetext{
${ }^{1}$ Universidade Federal do Ceará, Herbário EAC, Lab. Sistemática e Ecologia Vegetal (LASEV), bl. 906, Campus do Pici, 60440-900, Fortaleza, CE, Brasil.

${ }^{2}$ Universidade Federal Rural de Pernambuco, Depto. Biologia, Prog. Pós-graduação em Botânica, Av. Dom Manoel de Medeiros s/n, Dois Irmãos, 52171-900, Recife, PE, Brasil.

3 Universidade Federal do Piauí, R. Cícero Duarte 905, Junco, Campus Sen. Helvídio Nunes de Barros, 64600-000, Picos, PI, Brasil.

${ }^{4}$ Autor para correspondência: iloiola@ufc.br
} 
em duas séries e geralmente conatos na base; ovário súpero, 5-carpelar, 5-locular, uni a pluriovulado, estiletes 5, livres ou concrescidos; fruto cápsula loculicida ou baga (Lourteig 1983; Fiaschi 2010).

Algumas espécies são conhecidas popularmente como azedinhas ou azedeiras devido à presença do ácido oxálico, ou trevos, em referência ao número e disposição dos folíolos (Lourteig 1983). Dentre as espécies com potencial econômico destacam-se Avehrroa carambola L., popularmente conhecida como caramboleira, e Averrhoa bilimbi L. denominada carambola amarela, bilimbi ou limão de caiena, cujos frutos são comestíveis e usados na forma de sucos, geléias, compotas, doces caseiros e saladas (Lourteig 1983). A madeira de $A$. bilimbi é utilizada para a fabricação de utensílios domésticos como pentes e bastidores de bordar (Lourteig 1983). O suco de $A$. carambola é também usado na medicina popular como febrífugo, antiescorbútico e antidisentérico (Donadio et al. 2001). Algumas espécies de Oxalis são consideradas ornamentais pela beleza de suas inflorescências (Knuth 1930; Corrêa 1984) ou invasoras de culturas (Kissmann \& Groth 2000).

Dentre os gêneros que compõem a família, destaca-se Oxalis L. que compreende aproximadamente 700 espécies (Stevens 2001). É o gênero mais representativo em número de espécies e possui registros em diferentes domínios fitogeográficos e tipos de vegetação (BFG 2015), ocorrendo desde ambientes abertos como campos, até florestas e áreas antropizadas (Fiaschi \& Abreu 2005). É também o gênero mais estudado e alguns tratamentos focando as espécies sul-americanas foram realizados por Lourteig (1983, 1994, 2000), que propôs novas categorias infragenéricas e descrições de espécies novas. Lourteig (1994, 2000) com base principalmente em caracteres morfológicos (hábito, tamanho das folhas, disposição das flores nas inflorescências) e distribuição geográfica reconheceu quatro subgêneros (Oxalis subg. Oxalis L., O. subg. Thamnoxys (Endl.) Reiche, O. subg. Monoxalis (Small) Lourteig e $O$. subg. Trifidus Lourteig) e 28 seções. Esta é a classificação infragenérica mais aceita pelos especialistas da família.

No Brasil, Oxalidaceae está representada por dois gêneros nativos (Biophytum e Oxalis) e um naturalizado (Averrhoa) compreendendo 103 espécies, das quais 55 são endêmicas (BFG 2015). Os representantes da família foram citados tanto em floras regionais, estaduais e de localidades pontuais. Dentre as floras regionais, destacamos a lista de espécies do nordeste brasileiro (Barbosa et al. 2006), e ainda as listas de espécies de Oxalis da Mata Atlântica (Abreu \& Fiaschi 2009) e de espécies raras no Brasil (Conceição 2009).

Entre as floras estaduais destaca-se que para Santa Catarina, Lourteig (1983) registrou 40 táxons; para São Paulo, Fiaschi \& Conceição (2005) reconheceram 23 espécies; para Pernambuco, Abreu et al. (2008) registraram nove espécies; para o Acre, Daly \& Silveira (2008) listaram noves espécies; para Alagoas, Lemos et al. (2010) registraram nove espécies; para Sergipe, Costa-Lima \& Alves (2013) citaram nove espécies e para o Rio Grande do Sul, Grigoletto et al. (2014) reconheceram 27 espécies. Considerando as floras locais, ressaltase que no estudo desenvolvido por Nunes-Vidal et al. (1987) para o município de Viçosa - MG, foram registradas quatro espécies; Conceição \& Giulietti $(1998,2004)$ listaram para a serra do Cipó - MG e Grão-Mogol - MG cinco e quatro espécies, respectivamente; já para o município de Mirindiba - PE, Abreu \& Sales (2009) citaram duas espécies. Especificamente para o Ceará, nenhum estudo taxonômico contemplando esta família foi desenvolvido e as espécies de Oxalidaceae estão pobremente representadas nas listas florísticas de áreas específicas do referido estado (Araújo et al. 2011; Ribeiro-Silva et al. 2012; Loiola et al. 2015).

O objetivo do presente estudo foi registrar e atualizar a distribuição dos representantes de Oxalidaceae ocorrentes em território cearense. Ressalta-se que esse estudo está vinculado ao "Projeto Flora do Ceará", que teve início em 2009.

\section{Material e Métodos}

Para a elaboração da chave de identificação, descrições e comentários sobre a distribuição geográfica dos táxons de Oxalidaceae foram analisados espécimes obtidos em campo no período março/2011 a maio/2015 e coleções pertencentes aos Herbários ASE, EAC, HUEFS, RB e UFRN, cujas siglas estão de acordo com Thiers (2016). As descrições das espécies foram baseadas principalmente em amostras do Ceará. No entanto, a descrição de Oxalis puberula Nees \& Mart. não seguiu o padrão das demais, porque o único exemplar registrado para o Ceará, encontrase apenas em estádio vegetativo e desta forma, recorreu-se à análise do protólogo e de coleções oriundas de outros estados brasileiros.

A identificação das espécies foi baseada em literatura especializada (Lourteig 1983, 1994, 2000; Abreu et al. 2008) Foram feitas ainda consultas on 
line à coleções-tipo depositadas nos herbários $\mathrm{P}$, K. As abreviaturas dos autores dos táxons estão de acordo com o sítio do IPNI (2016). A terminologia morfológica seguiu Radford et al. (1974) e Gonçalves \& Lorenzi (2011).

Os representantes de Averrhoa não foram inclusos neste estudo por não serem nativos. Também foram desconsideradas as espécies ornamentais Oxalis tetraphylla Cav. e O. hedysaroides Kunth, que são encontradas frequentemente em canteiros de áreas urbanas.

Os dados de distribuição geográfica foram sistematizados com o uso de quadrículas georreferenciadas para o estado do Ceará (Fig. 1, Menezes et al. 2013). Para a classificação da vegetação foram usados os nomes locais e buscaramse os termos correspondentes no Manual Técnico da Vegetação Brasileira (IBGE 2012): savana (Cerrado), savana estépica (Caatinga/Carrasco), floresta estacional decidual (mata seca), floresta ombrófila densa (mata úmida) e floresta estacional semidecidual das terras baixas (mata de tabuleiro).

\section{Resultados e Discussão}

Para o Ceará foram registrados 14 táxons pertencentes ao gênero Oxalis. A espécie $O$. divaricata Mart. ex Zucc. foi a que apresentou mais ampla distribuição e teve registro em todos os tipos de vegetação do estado. $O$. cratensis Hooker, O. frutescens L., O. glaucescens Norlind e $O$. juruensis Diels var. juruensis foram registradas em três tipos vegetacionais (floresta ombrófila densa, floresta estacional semidecidual e savana estépica). Já Oxalis alstonii Lourteig, O. corniculata L., $O$. debilis Kunth, O. grisea A. St.-Hil \& Naudin, $O$. hedysarifolia Raddi, O. psoraleoides Kunth, $O$. puberula Nees \& Mart. e O. triangularis A. St.-Hil. foram encontradas apenas em floresta ombrófila densa. Sete espécies (O. cratensis, O divaricata, $O$. frutescens, O. glaucescens, O. grisea, O. juruensis e $O$. triangularis) foram registradas em diferentes
Unidades de Conservação (UC) no território cearense.

Destacamos que BFG (2015) registraram Oxalis gardneriana Progel para o Ceará, baseados na exsicata P. von Luetzelburg 26310, depositada no Herbário M (Munique/Alemanha). No entanto, não tivemos êxito na solicitação de empréstimo desta coleção e optamos por não considerar esta espécie no presente estudo.

\section{Tratamento taxonômico}

Oxalis L., Sp. Pl. ed 1. 433-435. 1753.

Ervas, subarbustos ou arbustos. Raízes fibrosas, tuberosas, ou napiformes. Caules aéreos, podendo ser herbáceos ou lenhosos, eretos, prostrados ou subterrâneos, os quais podem ser bulbosos, rizomatosos ou tuberosos. Folhas compostas, alternas, subopostas, ou pseudoverticiladas, geralmente trifolioladas, digitadas ou pinadas, raro unifolioladas ou filodiais; com ou sem estípulas; pecíolos cilíndricos, filodiais ou alados. Folíolos ovados, obovados, suborbiculares, elipsoides, obcordados ou obtriangulares. Inflorescências axilares; cimeiras dicasiais a umbeliformes, multifloras. Flores heterostílicas, actinomorfas, pentâmeras, monoclinas. Sépalas livres, com prefloração imbricada, persistentes nos frutos. Pétalas soldadas na porção mediana, unguiculadas. Estames 10, dispostos em dois verticilos; os maiores alternipétalos, com ou sem lígula; os menores, opositipétalos. Ginóforo pouco desenvolvido; androginóforo presente ou não. Ovário súpero, gamocarpelar, 5-carpelar, 5-locular, óvulos 1-15 por lóculo; estiletes 5, livres ou concrescidos até a porção mediana, pilosos, persistentes nos frutos; estigmas capitados, papilosos. Cápsula loculicida com deiscência explosiva, globosa, ovoide ou cilíndrica, 5-lobada. Sementes ovoides, achatadas lateralmente; testa crustácea; longitudinalmente costadas e transversalmente estriadas, foveoladas ou verrucosas.

\section{Chave de identificação das espécies de Oxalis registradas no estado do Ceará}

1. Folhas digitadas.

2. Caule aéreo, prostrado; pétalas amarelas

2. Oxalis corniculata

2'. Caule subterrâneo, bulboso; pétalas róseas a lilases.

3. Bulbos arredondados; folíolos obcordiformes 5. Oxalis debilis

3'. Bulbos alongados; folíolos obtriangulares 14. Oxalis triangularis

1'. Folhas pinadas.

4. Erva prostrada 8. Oxalis glaucescens

4'. Erva ou arbusto ereto. 
5. Pétalas róseas.

6. Folíolos elípticos a ovados; ramos glabros

3. Oxalis cratensis

6'. Folíolos lanceolados; ramos pubescentes

4. Oxalis cytisoides

5'. Pétalas esbranquiçadas ou amarelas.

7. Sementes 1 por lóculo.

8. Ramos e folhas glabros

1. Oxalis alstonii

8'. Ramos e folhas pubescentes a tomentosos.

9. Pétalas esbranquiçadas; cápsula subglobosa

13. Oxalis puberula

9'. Pétalas amarelas; cápsula ovoide

12. Oxalis psoraleoides

7'. Sementes 2-5 por lóculo.

10. Sementes com fendas nas depressões entre as estrias; ramos com tricomas esbranquiçados a amarelo-alaranjados.

11. Folíolos com ápice retuso, truncado a arredondado; cápsula sem tricomas glandulares nas linhas de suturas entre os carpelos

9. Oxalis grisea

11'. Folíolos com ápice obtuso a arredondado; cápsula com tricomas glandulares nas linhas de sutura entre os carpelos 11. Oxalis juruensis

10'. Sementes sem fendas nas depressões entre as estrias; ramos com tricomas translúcidos a esverdeados.

12. Ramos glabros a pubescente-glandulares; folíolos lineares a oblongos; cápsula pubescente-glandular

6. Oxalis divaricata

12'. Ramos tomentosos; folíolos elípticos, ovados ou trulados; cápsula glabra a pubescente.

13. Folhas pseudoverticiladas; folíolos elípticos a ovados 13'. Folhas alternas; folíolos trulados

7. Oxalis frutescens

10. Oxalis hedysarifolia

1. Oxalis alstonii Lourteig, Bradea 2(44): 292.1978.

Figs. 1; 2a,b; 3a,b

Erva ou subarbusto $20-70 \mathrm{~cm}$ alt.; caule aéreo, ereto. Ramos glabros; internós até ca. 7,5 $\mathrm{cm}$ compr. Folhas alternas ou pseudoverticiladas, pinadas, glabras, concentradas no ápice dos ramos; estípulas ausentes; pecíolo 3,5-7 cm compr., canaliculado, glabro a levemente pubescente; peciólulo ca. $1 \mathrm{~mm}$ compr., cilíndrico, glabro; raque foliar 6-10 $\mathrm{mm}$ compr., glabra; folíolo terminal 2-4 × 1,2-2 cm, elíptico a ovado, ápice agudo a obtuso, base obtusa a arredondada, margem inteira; folíolos laterais 1-3,5 × 0,5-1,5 $\mathrm{cm}$, semelhantes ao terminal. Cimeiras dicasiais, 1-3-floras; pedúnculo 1,5-8 cm compr., cilíndrico, glabro; brácteas ca. $1 \mathrm{~mm}$ compr., 1-2 por flor, lineares, levemente pubescentes. Flores tristílicas; pedicelo 2-4 mm compr., piloso. Sépalas 3,5-4 $\times 1-1,2 \mathrm{~mm}$, lineares a lanceoladas, levemente pubescentes, verdes a vináceas. Pétalas $6-8 \mathrm{~mm}$ compr., obovadas a espatuladas, amarelas; unha ca. $1 \mathrm{~mm}$ compr.; tubo 2-3 mm compr. Estames curtos 1-1,5 mm compr.; estames longos 1,8-3 mm compr.; anteras $0,4-0,5 \mathrm{~mm}$ compr., suborbiculares. Androginóforo ausente. Ginóforo 0,2-0,3 mm compr. Ovário ca. $1 \mathrm{~mm}$ compr., suborbicular, glabro a levemente piloso; 1 óvulo por lóculo; estilete 3-3,2 mm compr., piloso; estigma capitado.
Cápsula 2,5-3 × 2-2,5 mm, subglobosa a oblonga, glabra. Sementes 1,5-2 × 1-1,2 mm, 1 por lóculo, elipsoides, achatadas dorsiventralmente, 5-6 costadas, transversalmente estriadas, foveoladas, com perfurações circulares a poligonais e fendas nas depressões entre as estrias.

Material examinado: Aratuba, Sítio Paulo Cardoso, 14.V.1980, fl. e fr., P. Martins \& E. Nunes (EAC 8586). Baturité, 8.III.2002, fl. e fr., A. Fernandes (EAC 31401). Guaramiranga, Pico Alto, 28.III.2015, fl. e fr., M.I.B. Loiola et al. 2534 (EAC). Pacoti, Pico Alto, 17.VI.1989, fl. e fr., M.A. Figueiredo et al. (EAC 16124). Quixeramobim, 19.VIII.2003, fl. e fr., A. Fernandes \& E. Nunes (EAC 32883). Ubajara, Planalto da Ibiapaba, 21.XII.2010, fl., E.B. Souza et al. 2043 (EAC).

É reconhecida por ser uma planta glabra, com caule ereto, folhas alternas ou pseudoverticiladas, concentradas no ápice dos ramos, pétalas amarelas e cápsula subglobosa a oblonga. No território brasileiro ocorre nos estados da Bahia, Ceará, Goiás e Minas Gerais no domínio dos cerrados e das caatingas (BFG 2015). No estado do Ceará, está frequentemente associada à floresta ombrófila densa (Fig. 1, quadrículas C2, D5, D6) e também foi registrada na savana estépica/caatinga (F5). Coletada com flores em fevereiro, março, maio, junho, agosto e dezembro, e com frutos entre os meses de fevereiro a agosto. Nome popular: azedinha. 


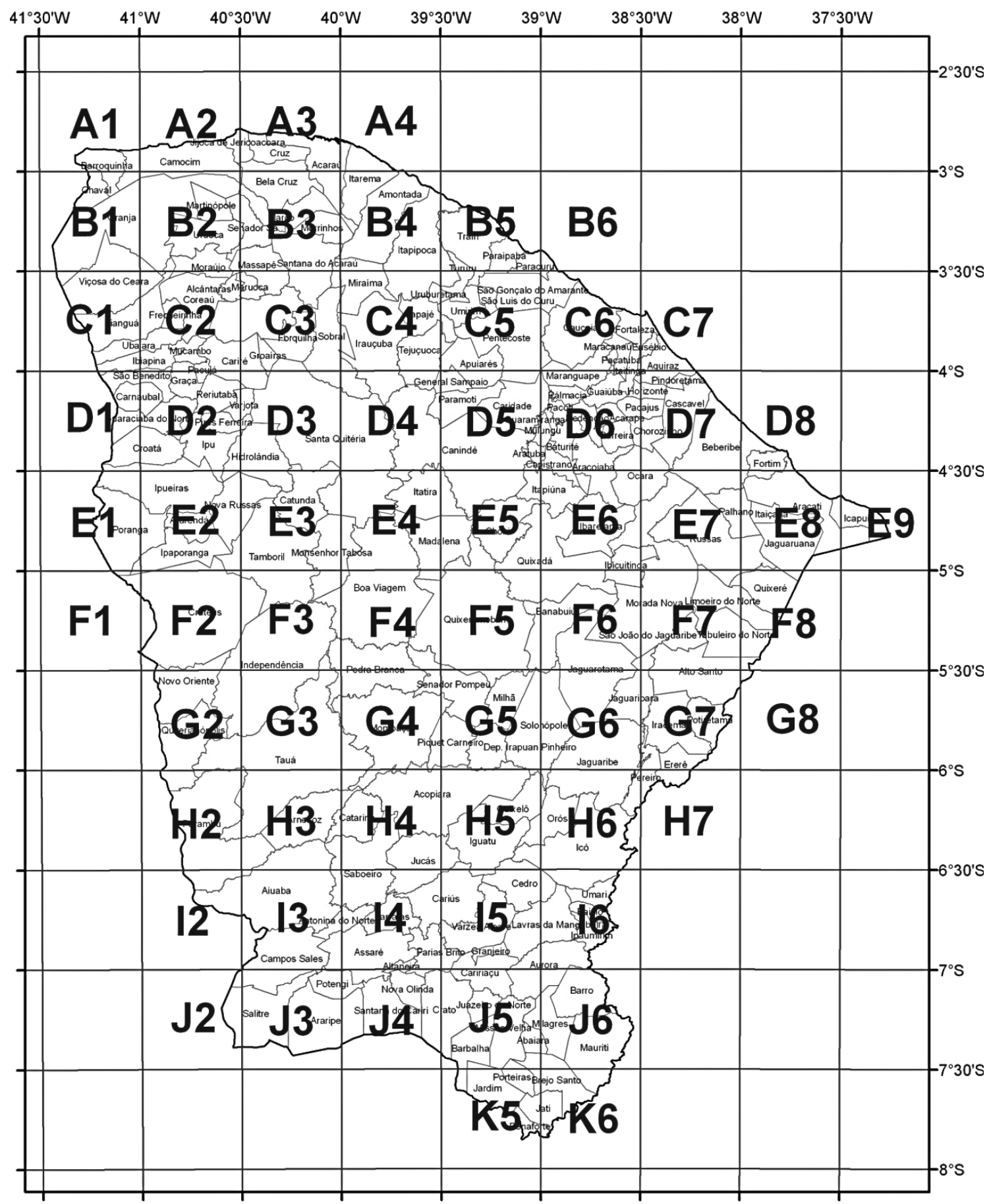

Figura 1 - Divisão política do estado do Ceará com grade de coordenadas de meio grau (A1-K6). Fonte: Menezes et al. (2013).

Figure 1 - Political division of the state of Ceará with a half degree grid (A1 - K6). Credits: Menezes et al. (2013). 
2. Oxalis corniculata L., Sp. Pl. 1: 435. 1753.

Figs. 1; 2c,d; 3c,d

Erva 5-7 cm alt.; caule aéreo, prostrado. Ramos pilosos; internós $0,4-1,5 \mathrm{~cm}$ compr. Folhas pseudoverticiladas, digitadas, pubescentes, não concentradas no ápice dos ramos; estípulas ca. 0,5 mm compr., soldadas na base do pecíolo; pecíolo 1,5-4 cm compr., cilíndrico, pubescente; peciólulo 0,5-1,5 mm compr., cilíndrico, pubescente; raque foliar $0,1-0,5 \mathrm{~mm}$ compr., glabra; folíolo terminal $0,3-0,4 \times 0,3-0,7 \mathrm{~cm}$, obcordiformes, ápice cordado, base obtusa, margem ciliada; folíolos laterais $0,5-1,5 \times 0,6-2 \mathrm{~cm}$, semelhantes ao terminal. Cimeiras dicasiais, 1-2-floras, falsamente umbeliformes; pedúnculo $0,5-4 \mathrm{~cm}$ compr., cilíndrico, pubescente; brácteas ca. $1 \mathrm{~mm}$ compr., 2 por flor, ovadas a lineares, densamente pubescentes. Flores tristílicas; pedicelo $0,6-1 \mathrm{~cm}$ compr., pubescente. Sépalas ca. 2,5 × $1 \mathrm{~mm}$, elípticas, levemente pubescentes na face externa, glabras na interna, verdes. Pétalas 7-9 mm compr., espatuladas, amarelas; unha ca. 0,5 mm compr.; tubo 1,2-1,5 $\mathrm{mm}$ compr. Estames curtos 3-3,2 mm compr.; estames longos 4-4,2 mm compr.; anteras ca. 0,3 $\mathrm{mm}$ compr., oblongo-elípticas. Androginóforo ausente. Ginóforo 0,4-0,5 mm compr. Ovário 1,2-1,3 mm compr.; oblongo, glabro; 4-12 óvulos por lóculo; estilete 2-2,2 mm compr., pubescente; estigma bilobado, papiloso. Cápsula ca. 1,5 × 0,3 $\mathrm{cm}$, cilíndrico-elipsoide, tomentosa. Sementes 1-2 $\times 0,5-1 \mathrm{~mm}, 4-12$ por lóculo, ovoides, achatadas dorsiventralmente, transversalmente estriadas, sem fendas nas depressões entre as estrias.

Material examinado: Guaramiranga, Pico Alto, 04'12'29"'S, 38 $8^{\circ} 58^{\prime} 23^{\prime}$ 'W, 28.III.2015, fl. e fr., M.I.B. Loiola et al. 2507 (EAC). Maranguape, Serra de Maranguape, 22.X.1992, fl. e fr., L.P. Félix (EAC 19850).

Distingue-se das demais espécies por ser uma erva com caule aéreo e prostrado, folíolos obcordiformes, estípulas com tamanho reduzido (ca. 0,5 mm compr.) e soldadas na base do pecíolo, pétalas amarelas e cápsula cilíndrico-elipsoide. É uma espécie ruderal, com distribuição em toda a América do Sul (Lourteig 2000). No Brasil, tem registro em todo o país (BFG 2015) e no estado do Ceará, a sua distribuição está restrita à floresta ombrófila densa (Fig. 1, quadrícula D6). Registrada com flores e frutos nos meses de março e outubro. Nome popular: azedinha.

3. Oxalis cratensis Hook., Icon. Pl. 4: t. 361. 1841.

Figs. $1 ; 2 \mathrm{e}-\mathrm{g} ; 3 \mathrm{e}, \mathrm{f}$

Erva ou subarbusto $20-60 \mathrm{~cm}$ alt., caule aéreo, ereto. Ramos glabros; internós 1,5-5,5 cm compr. Folhas alternas, subopostas ou opostas, pinadas, glabras, não concentradas no ápice dos ramos; estípulas ausentes; pecíolo 1,5-4 cm compr., cilíndrico, glabro a levemente pubescente; peciólulo ca. $1 \mathrm{~mm}$ compr., cilíndrico, pubescente; raque foliar 4-6 mm compr., glabra a levemente pubescente; folíolo terminal 1,6-4 × 0,5-2 cm, elíptico a ovado, ápice agudo a obtuso, base obtusa a arredondada, margem inteira; folíolos laterais $0,8-3,5 \times 0,5-1,5 \mathrm{~cm}$, semelhantes ao terminal. Cimeiras dicasiais, 3-12-floras; pedúnculo 1,1-5,8 $\mathrm{cm}$, cilíndrico, glabro; brácteas ca. $1 \mathrm{~mm}$ compr., 1-2 por flor, lanceoladas, levemente pubescentes. Flores tristílicas; pedicelo 2-4 mm compr., glabro. Sépalas 3-4 × 1-1,2 mm, lanceoladas, glabras a levemente pubescentes na face externa, glabras na interna, esverdeadas ou róseas. Pétalas $7-10 \mathrm{~mm}$ compr., espatuladas, róseas; unha ca. $1 \mathrm{~mm}$ compr.; tubo 2-4 mm compr. Estames curtos 1,4-2,5 $\mathrm{mm}$ compr.; estames longos 2-4,5 mm compr.; anteras $0,5 \times 0,4 \mathrm{~mm}$, oblongas. Androginóforo ausente. Ginóforo $0,1-0,5 \mathrm{~mm}$. Ovário $0,75-1,1$ mm compr., obclavado, 5-anguloso, glabro; 3-4 óvulos por lóculo; estilete $0,4-3 \mathrm{~mm}$ compr., glabro a pubescente; estigma capitado a subcapitado ou bilobado. Cápsula 4-6 × 3-4 mm, globosaelipsoide, levemente 5-costada, glabra. Sementes 1,8-2 × 0,8-1 mm, 3-4 por lóculo, elipsoides, discretamente achatadas dorsiventralmente, 5costadas, transversalmente estriadas, sem fendas nas depressões entre as estrias.

Material selecionado: Aratuba, descida Aratuba Capistrano, 6.VI.2000, fl. e fr., A. Fernandes (EAC 29862). Baturité, encosta da Serra de Baturité, 8.III.2002, fl. e fr., A. Fernandes (EAC 31398). Capistrano, Serra do Vicente, 13.V.1980, fl. e fr., E. Nunes \& P. Martins (EAC 8561). Crato, 29.IV.2001, fl., A. Fernandes \& Lorenzi (EAC 30616). Redenção, 04¹0'29'S, 38²4'56”'W, 29.III.2015, fl. e fr., M.I.B. Loiola et al. 2580 (EAC). Pacoti, Serra de Baturité, 1.III.1992, fl. e fr., M.A. Figueiredo (EAC 18492). Santa Quitéria, próximo a Serra do Quati, 7.VI.1984, fl. e fr., M.A. Figueiredo et al. (EAC 12696). Sobral, EMBRAPA Caprinos, 15.V.2002, fl. e fr., M. Mamede 85 (EAC). Ubajara, Sede PARNAPl. da Ibiapaba, 24.II.1999, fl. e fr., A. Fernandes et al. (EAC 27860).

Pode ser facilmente reconhecida pelo caule aéreo e ereto, ramos glabros, folhas pinadas, folíolos elípticos a ovados, pétalas róseas e cápsula globosa-elipsoide. Ocorre na Bolívia, Paraguai e Brasil (Lourteig 1994). No território brasileiro esta espécie não foi observada apenas na Região Sul do país (BFG 2015). No Ceará cresce em floresta ombrófila densa, floresta estacional decidual e 


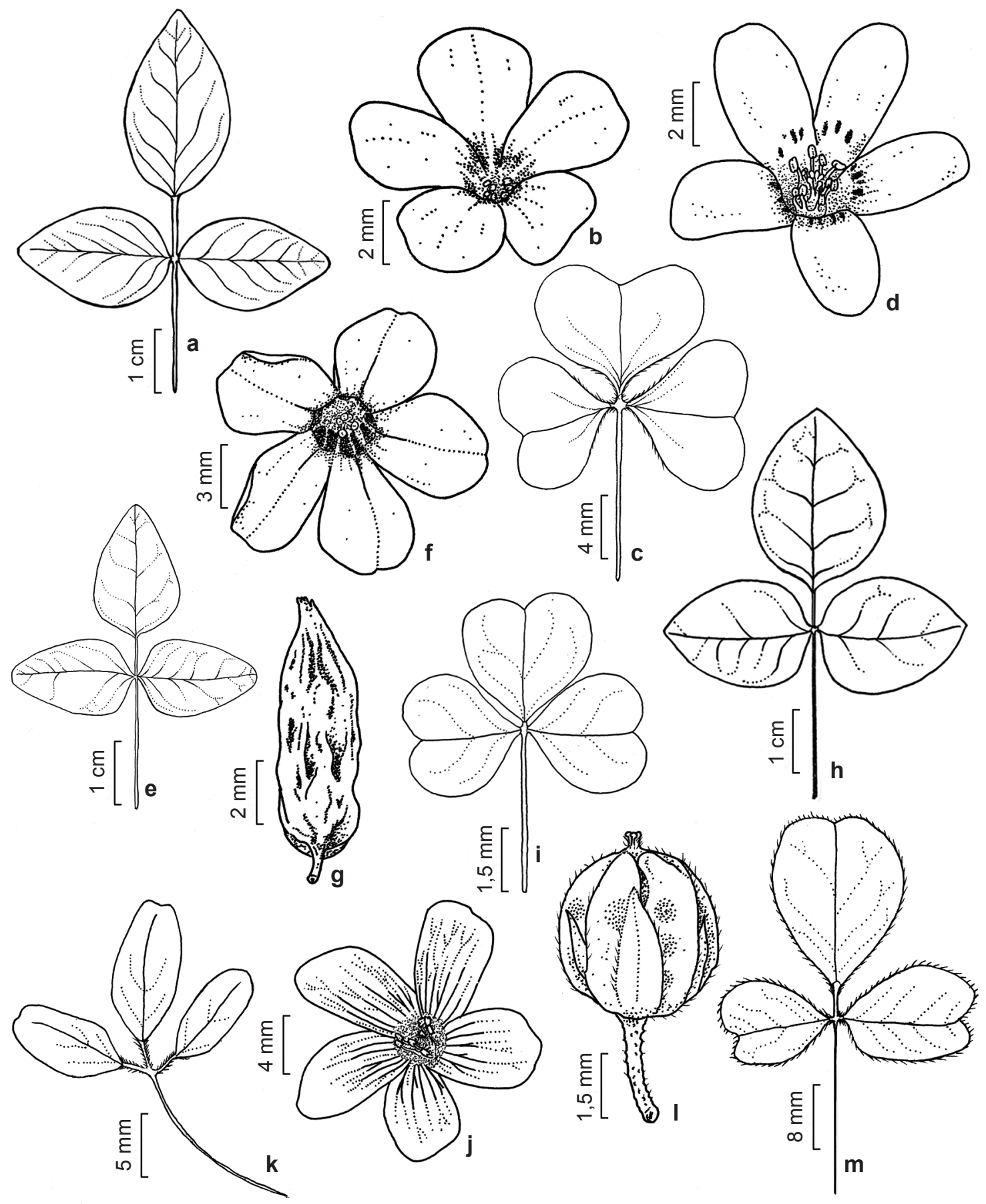

Figura 2 - a,b. Oxalis alstonii - a. folha; b. fruto. c,d. O. corniculata - c. folha; d. fruto. e-g. O. cratensis - e. folha; f. flor; g. fruto. h. O. cytisoides - folha; i,j. O. debilis - i. folha; j. flor. k,1. O. divaricata - k. flor; 1. fruto. m. $O$. frutescens - folha. (a,b. M.I.B. Loiola et al. 2534; c,d. M.I.B. Loiola et al. 2507; e-g. M.I.B. Loiola et al. 2580 ; h. A. Duarte e Ivone 1370; i,j. M.I.B. Loiola 2460; k,1. M.I.B. Loiola 2609; m. L.W. Lima-Verde 495).

Figure 2 - a-b. Oxalis alstonii - a. leaf; b. fruit; c-d. O. corniculata - c. leaf; d. fruit; e-g. O. cratensis - e. leaf; f. flower; g. fruit; h. O. cytisoides - leaf; i-j. O. debilis - i. leaf; j. flower; k-1. O. divaricata - k. flower; 1. fruit; m. O. frutescens - leaf. (a,b. M.I.B. Loiola et al. 2534; c,d. M.I.B. Loiola et al. 2507; e-g. M.I.B. Loiola et al. 2580; h. A. Duarte e Ivone 1370; i,j. M.I.B. Loiola 2460; k,1. M.I.B. Loiola 2609; m. L.W. Lima-Verde 495). 

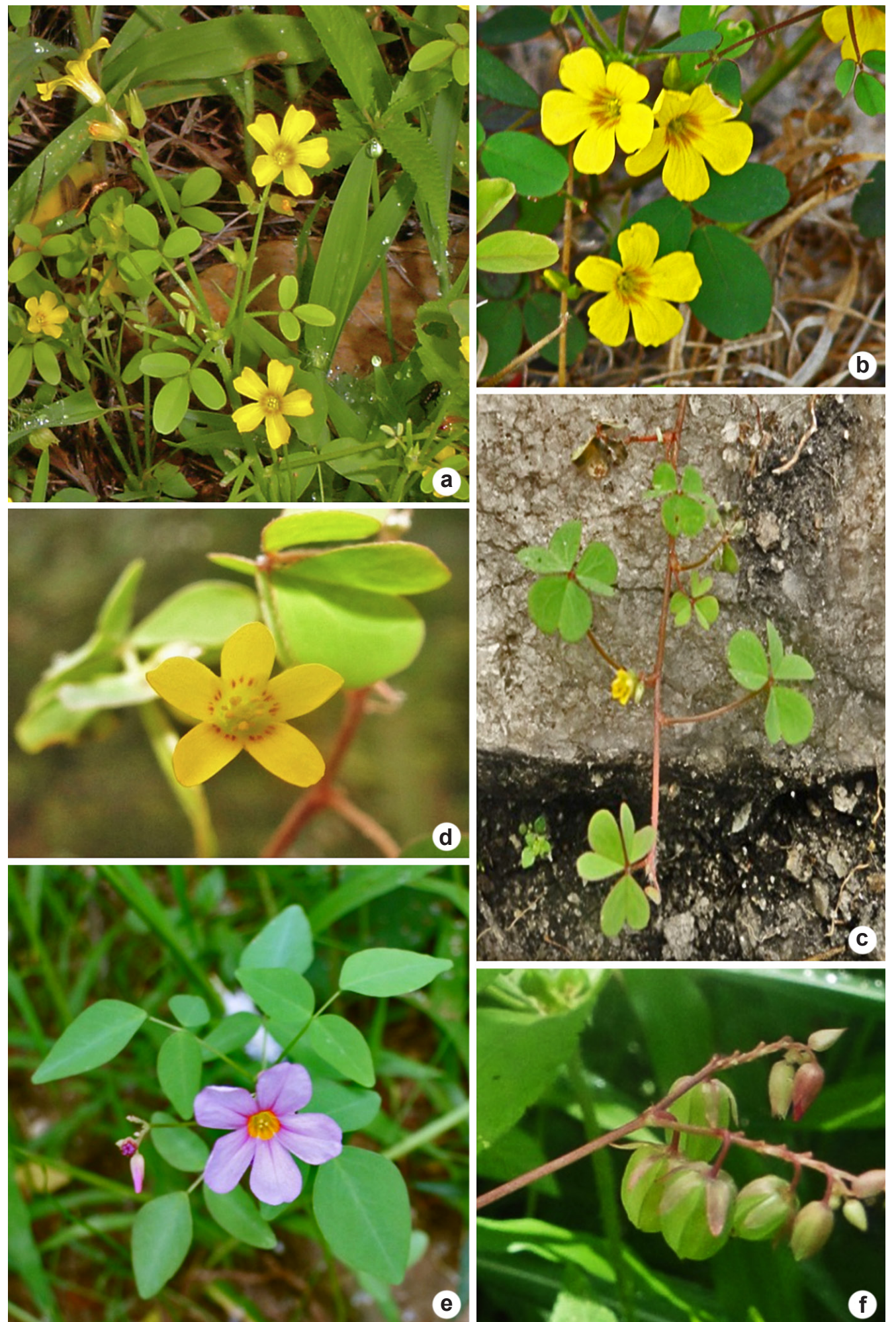

Figura 3 - Oxalidaceae no Ceará - a,b. Oxalis alstonii - a. hábito; b. flores. c,d. O. corniculata - c. hábito; d. flores. e,f. O. cratensis - e. hábito; f. frutos. Fotos: a-f. M.I.B. Loiola.

Figure 3 - Oxalidaceae of Ceará - a,b. Oxalis alstonii - a. habit; b. flowers. c,d. O. corniculata - c. habit; d. flowers. e,f. O. cratensis - d. habit; e. fruit. Photos: a-f. M.I.B. Loiola. 
savana estépica/caatinga, geralmente próximo a cursos d'água (Fig. 1, quadrículas C2, C3, D3, D5, D6, J5). Coletada com flores entre os meses de fevereiro a setembro, e com frutos de fevereiro a agosto. Nome popular: azedinha, erva-imbu.

4. Oxalis cytisoides Mart. ex Zucc., Denkschr. Akad. Munchen 9: 178. 1823-24. Figs. 1; 2h

Subarbusto ca. $50 \mathrm{~cm}$ alt., caule aéreo, ereto. Ramos pubescentes; internós 2-5,5 cm compr. Folhas alternas a subopostas, pinadas, glabras, não concentradas no ápice dos ramos; estípulas ausentes; pecíolo 2-4 cm compr., cilíndrico, glabro a levemente pubescente; peciólulo ca. $1 \mathrm{~mm}$ compr., cilíndrico, pubescente; raque foliar 3-8 mm compr., levemente pubescente; folíolo terminal 1,6-7 $\times$ 1-2,5 cm, lanceolado, ápice agudo a acuminado, base obtusa a arredondada, margem inteira; folíolos laterais $1,5-3,5 \times 0,5-1,5 \mathrm{~cm}$, semelhantes ao terminal. Cimeiras dicasiais, 2-floras; pedúnculo 3,2-6,8 cm compr., cilíndrico, pubescente; brácteas ca. $1 \mathrm{~mm}$ compr., 1-2 por flor, lanceoladas, levemente pubescentes. Flores tristílicas; pedicelo 2-3 mm compr., pubescente. Sépalas 3-4 × 1-2 $\mathrm{mm}$, lanceoladas, levemente pubescentes na face externa, glabras na interna, róseas. Pétalas 7-9 mm compr., oblongo-espatuladas a obtusas, róseas; unha ca. $1 \mathrm{~mm}$ compr.; tubo 2-3 $\mathrm{mm}$ compr. Estames curtos 1-3 mm compr.; estames longos 2-4 mm compr.; anteras ca. 0,5 mm compr., oblongas. Androginóforo ausente. Ginóforo 0,2-0,4 mm compr. Ovário ca. 0,75-1 mm compr.; obclavado, glabro; 2-3 óvulos por lóculo; estilete ca. 0,5 mm compr., piloso; estigma bilobado. Cápsula 3-5 × 1,5-2 mm, globosa-elipsoide, glabra. Sementes ca. $2 \times 1 \mathrm{~mm}, 2-3$ por lóculo, ovoide, achatadas dorsiventralmente, levemente 5-costada, transversalmente estriadas, sem fendas nas depressões entre as estrias.

Material examinado: Crato, base da Serra do Araripe, represa da usina do Crato, 8.VIII.1948, fl., A. Duarte \& Ivone $1370(\mathrm{RB})$.

Material adicional: BRASIL. MINAS GERAIS: Grão Mogol, estrada entre Grão Mogol e Cristália, 2.IV.2005, fl. e fr., E.B. Souza (EAC 35859, HUEFS 94023). RIO DE JANEIRO: Varre-Sai, estrada para balança, 23.VIII.2005, fl. e fr., R. Marquete et al. 3662 (RB).

$\mathrm{O}$ conjunto de caracteres que auxiliam no reconhecimento desta espécie são o caule aéreo ereto, folhas pinadas, folíolos lanceolados e pétalas róseas. Distribui-se pela Argentina e Brasil (Lourteig 1994). No território brasileiro foi registrada em todas as regiões do país (BFG 2015).
No Ceará, esta espécie foi considerada rara, estando representada por uma única coleta na Chapada do Araripe em floresta estacional semidecidual (Fig. 1, quadrícula J5). Com flores em abril e agosto, e com frutos em abril. Nome popular: azedinha.

5. Oxalis debilis Kunth, Nov. Gen. Sp. v. 236. t. 466. 1821 . Figs. $1 ; 2 \mathrm{i}, \mathrm{j} ; 4 \mathrm{a}, \mathrm{b}$

Erva bulbosa, 10-30 cm alt.; caule subterrâneo. Bulbos 1,2-3 cm compr., arredondados, rizomatosos; estolões presentes, produzindo bulbilhos secundários; bulbos escamosos, escamas externas 3,5-4 × 3-3,5 mm, membranáceas, ovado-arredondadas, escamas internas não observadas. Folhas alternas, digitadas, glabras a levemente pubescentes, não concentradas no ápice dos ramos; estípulas ausentes; pecíolo 9-20 cm compr., cilíndrico, piloso; peciólulo ca. 0,5 mm compr., cilíndrico, hirsuto; raque foliar 0,8-1 mm compr., tomentosa; folíolo terminal 2-3,4 × 2,6-5 cm, obcordiformes, ápice retuso, base aguda, margem ciliada com pontuações amarronzadas a enegrecidas em ambas as faces; folíolos laterais $1-3,5 \times 0,5-1,5 \mathrm{~cm}$, semelhantes ao terminal. Cimeiras dicasiais 2-10-floras, umbeliformes; pedúnculo 18-35 cm compr., cilíndrico, viloso; brácteas $1-2 \times 0,5 \mathrm{~mm}, 2$ por flor, ovado-acuminadas, glabras. Flores tristílicas; pedicelo 1-2,4 cm, glabro. Sépalas 4-4,2 × 1-1,5 $\mathrm{mm}$, ovadas a oblongas com duas calosidades alaranjadas no ápice, glabras, esverdeadas. Pétalas 1,1-1,4 cm compr., espatuladas, róseas a lilases; unha ca. $1 \mathrm{~mm}$ compr.; tubo 3-4 mm compr. Estames curtos 2-4,2 mm compr., estames longos 3,5-6 mm compr.; anteras 0,3-0,5 mm compr., oblongas. Androginóforo ausente. Ginóforo 0,3-1,1 mm compr. Ovário 2-2,3 mm compr., obclavado, pubescente; 8-12 por lóculo; estilete 0,3-0,5 mm compr.; estigma capitados a bilobados. Cápsula não observada.

Material examinado: Guaramiranga, Pico Alto, 04¹2'29'S, 3858'23'W, 28.III.2015, fl., M.I.B. Loiola 2504 (EAC). Maranguape, trilha Pirapora, 353'17'S, 3842'58'W, fl., 27.IX.2014, M.I.B. Loiola 2460 (EAC).

Pode ser reconhecida pelo hábito herbáceo bulboso, folhas obcordadas com pontoações amarronzadas a enegrecidas em ambas as faces, e pétalas espatuladas, róseas a lilases. Ocorre na América do Sul, Antilhas e Velho Mundo (Lourteig 1994). No Brasil foi registrada em todas as regiões do país (BFG 2015). Já no território cearense sua distribuição está restrita às serras úmida, desenvolvendo-se em floresta ombrófila densa 

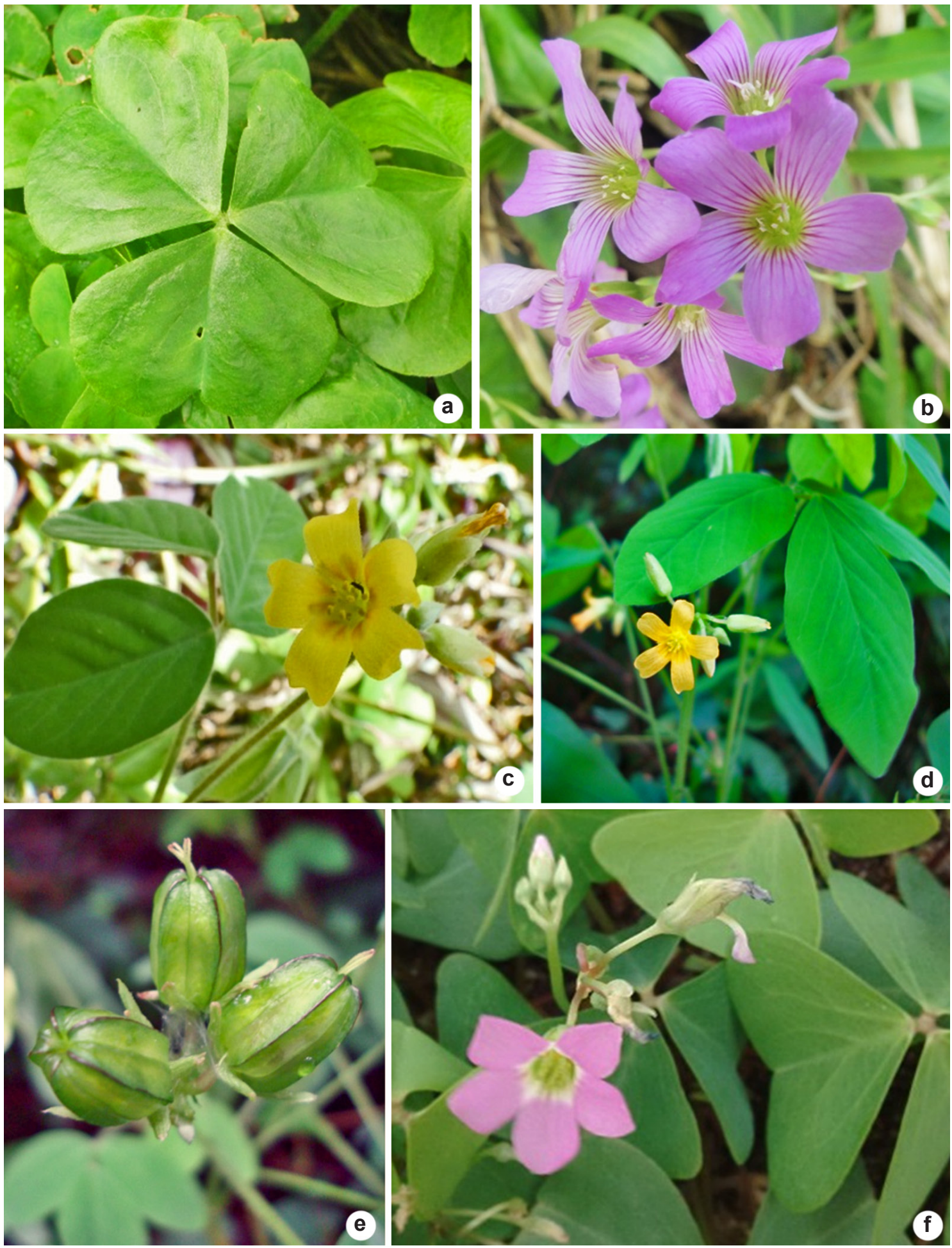

Figura 4 - Oxalidaceae no Ceará - a,b. Oxalis debilis - a. folha; b. inflorescência. c. O. grisea - folha, botão e flor. d,e. $O$. hedysarifolia - d. folha e inflorescência; e. frutos. f. O. triangularis - f. folhas, botões e flor. Fotos: a-f. M.I.B. Loiola.

Figure 4 - Oxalidaceae of Ceará - a,b. Oxalis debilis - a. leaf; b. inflorescence. c. O. grisea - leaf, buds and flower. d,e. O. hedysarifolia - d. leaf and inflorescence; e. fruits. f. O. triangularis - f. leaf, buds and flower. Photos: a-f. M.I.B. Loiola. 
(Fig. 1, quadrícula D6). Coletada com flores em março e setembro. Nome popular: azedinha, trevo.

6. Oxalis divaricata Mart. ex Zucc., Denkscr. Konigl. Akad. Wiss. Munchen Ser. 1. 9:169. 1825.

Figs. $1 ; 2 \mathrm{k}, 1$

Erva ou subarbusto $10-50 \mathrm{~cm}$ alt., caule aéreo, ereto. Ramos glabros a pubescenteglandular; internós $0,5-5 \mathrm{~cm}$ compr. Folhas alternas a subopostas, pinadas, glabras a levemente pubescentes; não concentradas no ápice dos ramos; estípulas ausentes; pecíolo 1-2,5 cm compr., cilíndrico, híspido; peciólulo 0,5-1 $\mathrm{mm}$ compr., cilíndrico, híspido a levemente glandular; raque foliar 1-5 mm compr., híspida a pubescente; folíolo terminal $0,4-3,2 \times 0,3-1 \mathrm{~cm}$, linear a oblongo, ápice retuso, agudo a obtuso, base aguda a arredondada, margem inteira; folíolos laterais $0,5-2,4 \times 0,3-1,2 \mathrm{~cm}$, semelhantes ao terminal. Cimeiras dicasiais, 3-8-floras; pedúnculo 1,3-5,7 $\mathrm{cm}$, cilíndrico, híspido; brácteas ca. $1 \mathrm{~mm}$ compr., 1-2 por flor, lanceoladas, glabras a híspidas. Flores tristílicas; pedicelo 1,5-2 mm compr., hirsuto a pubescente. Sépalas 3-4 × 1-1,5 mm, lanceoladas a ovadas, hirsutas a glandular-pubescentes na face externa, glabras na face interna ápice agudo; verdes a vináceas. Pétalas 7-9 mm compr., espatuladas, amarelas; unha ca. $1 \mathrm{~mm}$; tubo 3-4 $\mathrm{mm}$ compr. Estames curtos 1-2 mm compr., estames longos 2-3,5 mm compr.; anteras $0,2-0,5 \mathrm{~mm}$ compr., oblongas. Androginóforo ausente. Ginóforo $0,2-0,8$ mm compr. Ovário 0,4-1 mm compr., obclavado, 5-anguloso, glabro; 3 óvulos por lóculo; estilete ca. 0,3-2,5 mm compr., pubescente; estigma bilobado. Cápsula 3-4,5 × 4,2-4,5 mm, elipsoide a globosa, pubescente. Sementes 1-2 2 0,5-1 mm compr., 2 por lóculo, ovoides, 3-costadas longitudinalmente, transversalmente estriadas em zigue-zague, sem fendas nas depressões entre as estrias.

Material examinado: Aiuaba, ESEC de Aiuaba, 20.III.1991, fl. e fr., M.A. Figueiredo et al. 10 (EAC). Baturité, encosta da Serra de Baturité, 8.III.2002, fl. e fr., A. Fernandes (EAC 31399). Beberibe, Aroeiras, $04^{\circ} 03^{\prime} 08 \mathrm{~S}, 37^{\circ} 00^{\prime} 04^{\prime}$ 'W, 1.V.2015, fl. e fr., M.I.B. Loiola 2609 (EAC). Caridade, Fazenda Feijão, 22.IV.1990, fl. e fr., B. Freitas (EAC 16777). Caucaia, Parque Botânico, 17.IV.1998, fl., L.Q. Matias 81 (EAC). Crateús, RPPN Serra das Almas, 6.IV.2001, fl., M.S. Sobrinho \& M.M.A. Bruno (EAC 32967). Granja, Serra de Ubatuba, 26.IV.2002, fl. e fr., E.K.S. Brandão et al. 79 (EAC). Guaraciaba do Norte, Serra da Ibiapaba, 8.IV.1982, fl. e fr., P. Martins (EAC 11199). Irauçuba, Fazenda Cacimba Salgada, 5.V.2001, fl. e fr., A. Carvalho (EAC 31745). Nova Olinda, Sítio Sozinho, 6.V.2006, fl. e fr., sem coletor (EAC 39497). Novo Oriente, Estrondo, Planalto da Ibiapaba, 10.III.1991, fl. e fr., F.S. Araújo 352 (EAC). Palmácia, próximo ao Mundo Novo, 8.X.1980, fl. e fr., E. Nunes e P. Martins (EAC 8935). Pentecoste, Fazenda Jardim, 15.IV.2002, fl. e fr., F. Gonçalves (EAC 31715). Quixadá, Fazenda Iracema, 6.VI.1982, fl., E. Nunes (EAC 11616). Santa Quitéria, Serra do Pajé, Fazenda Intan de Cima, 7.V.1997, fl. e fr., M.A. Figueiredo 769 (EAC). Sobral, Fazenda MacapáTaperuaba, 1.V.2001, fl. e fr., A. Fernandes (EAC 30724). Tianguá, Chapada da Ibiapaba, 22.III.2000, fl. e fr., $A$. Fernandes (EAC 29066). Tururu, 8.IX.2013, fl., M.I.B. Loiola 2133 (EAC). Viçosa do Ceará, Sítio Engenho Velho, 29.IV.2010, fl., E.B. Souza 1822 (EAC, UFRN).

Tem como características marcantes ser uma planta herbácea ou subarbustiva com folíolos glabros a pubescente-glandulares, pétalas espatuladas e amarelas e cápsula de tamanho reduzido (3-4,5 mm compr.) globosa-elipsoide, pubescente-glandular. É endêmica do Brasil (Abreu et al. 2008), com registros em todos os estados da região nordeste, Goiás, Minas Gerais e Rio de Janeiro (BFG 2015). No Ceará é a espécie com mais ampla distribuição e ocorre em diferentes tipos de vegetação. Foi registrada na savana estépica/ caatinga, floresta estacional decidual, savana, floresta ombrófila densa e floresta estacional semidecidual de terras baixas (Fig. 1, quadrículas B2, C1, C3, C4, C5, C6, D2, D3, D5, D6, E6, F2, G2, I3, J4). Parece apresentar flores e frutos praticamente durante todo o não. Nome popular: azedinha.

7. Oxalis frutescens L., Sp. Pl. ed. 1. 435. 1753.

Figs. 1; $2 \mathrm{~m}$

Subarbusto ou arbusto $10-80 \mathrm{~cm}$ alt., caule aéreo, ereto. Ramos tomentosos; internós 0,7-6,3 $\mathrm{cm}$ compr. Folhas pseudoverticiladas, pinadas, pubescentes, frequentemente distribuídas em braquiblastos; estípulas ausentes; pecíolo 0,5-2,3 cm compr.; peciólulo ca. $1 \mathrm{~mm}$ compr., cilíndrico, glabro; raque foliar 3-6 $\mathrm{mm}$ compr., hirsuta; folíolo terminal $0,8-3 \times 0,5-1,4 \mathrm{~cm}$, elíptico a ovado, ápice retuso, agudo a arredondado, base aguda a arredondada, margem ciliada; folíolos laterais $0,5-2,5 \times 0,5-1,2 \mathrm{~cm}$, semelhantes ao terminal. Cimeiras dicasiais, 1-3-floras; pedúnculo 0,5-1,9 cm compr., cilíndrico, hirsuto; brácteas ca. 1,5 $\times 0,5 \mathrm{~mm}, 1-2$ por flor, lanceoladas, levemente pubescentes. Flores tristílicas; pedicelo $2-4 \mathrm{~mm}$ compr., hirsuto. Sépalas 4-5 × 1-2 mm, ovalacuminadas, hirsutas. Pétalas $6-12 \mathrm{~mm}$ compr., espatuladas, amarelas; unha $1-1,5 \mathrm{~mm}$ compr.; tubo 3-4 mm compr. Estames curtos 1-3,5 
mm compr.; estames longos 3-6 mm compr., ligulados; anteras 0,4-0,5 mm compr., oblongas. Androginóforo ausente. Ginóforo 0,2-0,5 mm compr. Ovário 0,75-1 mm compr., obclavado a globoso, 5-anguloso, glabro; 2-5 óvulos por lóculo; estilete 0,3-3,5 mm compr., glabro a pubescente; estigma capitado a subcapitado ou bilobado. Cápsula 3-7 × 3-4 mm, globosa a oblonga, glabra a pubescente. Sementes $1-1,5 \times 0,5-1$ mm, 2-4 por lóculo, ovado-elipsoides, 5-costadas longitudinalmente, transversalmente estriadas, sem fendas nas depressões entre as estrias.

Material examinado: Aiuaba, Lagoa da Bioiada, 26.II.1997, fl. e fr., L.W. Lima-Verde 495 (EAC). Baturité, encosta da Serra de Baturité, 8.III.2002, fl. e fr., A. Fernandes (EAC 31400). Cedro, 17.IV.2011, fl. e fr., A. Fernandes \& H. Lorenzi (EAC 30626). Crateús, RPPN Serra das Almas, 25.II.2002, fl. e fr., F.S. Araújo \& J.R. Lima 1288 (EAC). Crato, Chapada do Araripe, 28.III.2000, fl. e fr., E.B. Souza 459 (EAC, UFRN). Pacoti, Sítio Santa Madalena, 9.X.1980, fl. e fr., E. Nunes \& P. Martins (EAC 8985). Tianguá, encosta do Rio Jaburu, 30.IV.1987, fl. e fr., A. Fernandes \& F. Matos (EAC 15113).

Diferencia-se das demais espécies por apresentar folhas pseudoverticiladas, pinadas, frequentemente distribuídas em braquiblastos, pétalas amarelas e cápsula globosa a oblonga. Está distribuída desde o México e Antilhas até o noroeste da Argentina (Lourteig 1994). No Brasil não tem registro apenas na região Sul (BFG 2015). No Ceará ocorre em vegetação de savana estépica/ carrasco, savana e floresta ombrófila densa (Fig. 1, quadrículas C1, D6, F2, I3, I5, J5). Floresce e frutifica nos meses de fevereiro, março, abril, maio e outubro. Nome popular: vinagreira-de-camaleão.

\section{Oxalis glaucescens Norlind, Ark. Bot. 14(6):} 15. 1915.

Figs. 1; 5a

Erva 20-40 cm compr., caule aéreo, prostrado. Ramos tomentosos; internós 0,2-5,4 cm compr. Folhas opostas a pseudoverticiladas, pinadas, não concentradas no ápice dos ramos; estípulas ausentes; pecíolo 1,5-2 cm compr., cilíndrico, tomentoso; peciólulo 0,5 mm compr., cilíndrico, glabro; raque foliar 1-2 mm compr., glabra; folíolo terminal 0,5-1 ×0,8-1,2 cm, obcordiforme, ápice emarginado, base aguda a obtusa, margem ciliada; folíolos laterais $0,4-0,7 \times 0,6-1 \mathrm{~cm}$, semelhantes ao terminal. Cimeiras dicasiais, 1-3-floras; pedúnculo 0,5-1 cm compr., cilíndrico, piloso; brácteas 1-2 mm compr., 1-2 por flor, lineares, tomentosas. Flores distílicas; pedicelo 2-3 $\mathrm{mm}$, cilíndrico, tomentoso. Sépalas 3-4 × 2-2,5 mm, elípticas, hirsutas na face externa, glabras na face interna, esverdeadas. Pétalas 4-7 mm compr., obovadas a levemente espatuladas, amarelas; unha 1-1,5 mm compr.; tubo 2-4 mm compr. Estames curtos 1-1,5 mm compr., estames longos $2 \mathrm{~mm}$ compr., ligulados; anteras 0,4-0,5 mm compr., oblongoelípticas. Androginóforo ausente. Ginóforo ca. 0,5 mm compr. Ovário 0,5-0,7 mm compr., globosopiriforme, puberulento, 1 óvulo por lóculo; estilete 0,5-1 mm compr., puberulento; estigma discoide. Cápsula 4,5-6 × 3-5,5 mm, globoide-achatada, pubescente, sépalas persistentes, patentes. Sementes 1,8-2 × 0,9-1 mm, 1 por lóculo, elipsoides, 5-6 costadas, transversalmente estriadas, sem fendas nas depressões entre as estrias.

Material examinado: Aiuaba, Letreiro, 11.IV.1991, fl. e fr., M.A. Figueiredo et al. 68 (EAC). Aratuba, Serra de Baturité, 9.VI.2000, fl. e fr., A. Fernandes (EAC 29859). Baturité, encosta da Serra de Baturité, 8.III.2002, fl. e fr., A. Fernandes (EAC 31397). Santa Quitéria, Fazenda Itataia, 26.IV.1984, fl., A. Fernandes et al. (EAC 12484). Sobral, Taperuaba, Fazenda Macapá, 12.V.1995, fl. e fr., A. Fernandes (EAC 22864).

Caracteriza-se por ser uma erva prostrada com folhas pinadas, folíolos obcordiformes, cimeiras dicasiais e cápsula globoide-achatada. Sua distribuição está restrita ao Brasil, com registro nas regiões Nordeste, Centro-Oeste e Sudeste (BFG 2015). No Ceará está associada a ambientes mais secos, como savana e savana estépica/carrasco (Fig. 1, quadrículas C3, D3, D5, D6, I3). Floresce nos meses de janeiro a junho, e frutifica de março a junho.

9. Oxalis grisea A. St-Hil. \& Naudin, Ann. Sci. Nat., Bot. sér. 2, 18: 28. 1842. Figs. 1; 4c; 5b-d

Arbusto 50-90 cm alt., caule aéreo, ereto. Ramos tomentosos a pubescentes; internós 1,5-3,5 cm compr. Folhas alternas, subopostas ou opostas, pinadas, glabras a pubescentes, não concentradas no ápice dos ramos; estípulas ausentes; pecíolo 1,5-3,5 cm compr., canaliculado, pubescente; peciólulo ca. $1 \mathrm{~mm}$ compr., cilíndrico, pubescente a tomentoso; raque foliar 2-6 $\mathrm{mm}$ compr., pubescente; folíolo terminal 1,2-3,2 $\times 0,8-2,5$ $\mathrm{cm}$, obovado a oblongo, ápice retuso, truncado a arredondado, base aguda a arredondada, margem ciliada; folíolos laterais $0,8-2,8 \times 0,6-2 \mathrm{~cm}$, semelhantes ao terminal. Cimeiras dicasiais, 1-5floras, umbeliformes; pedúnculo 1,2-5,7 cm, cilíndrico, piloso; brácteas 2-3 mm compr., 1-2 por flor, lineares, pilosas. Flores tristílicas; pedicelo 3-5 mm compr., pubescentes. Sépalas 2-3,5 


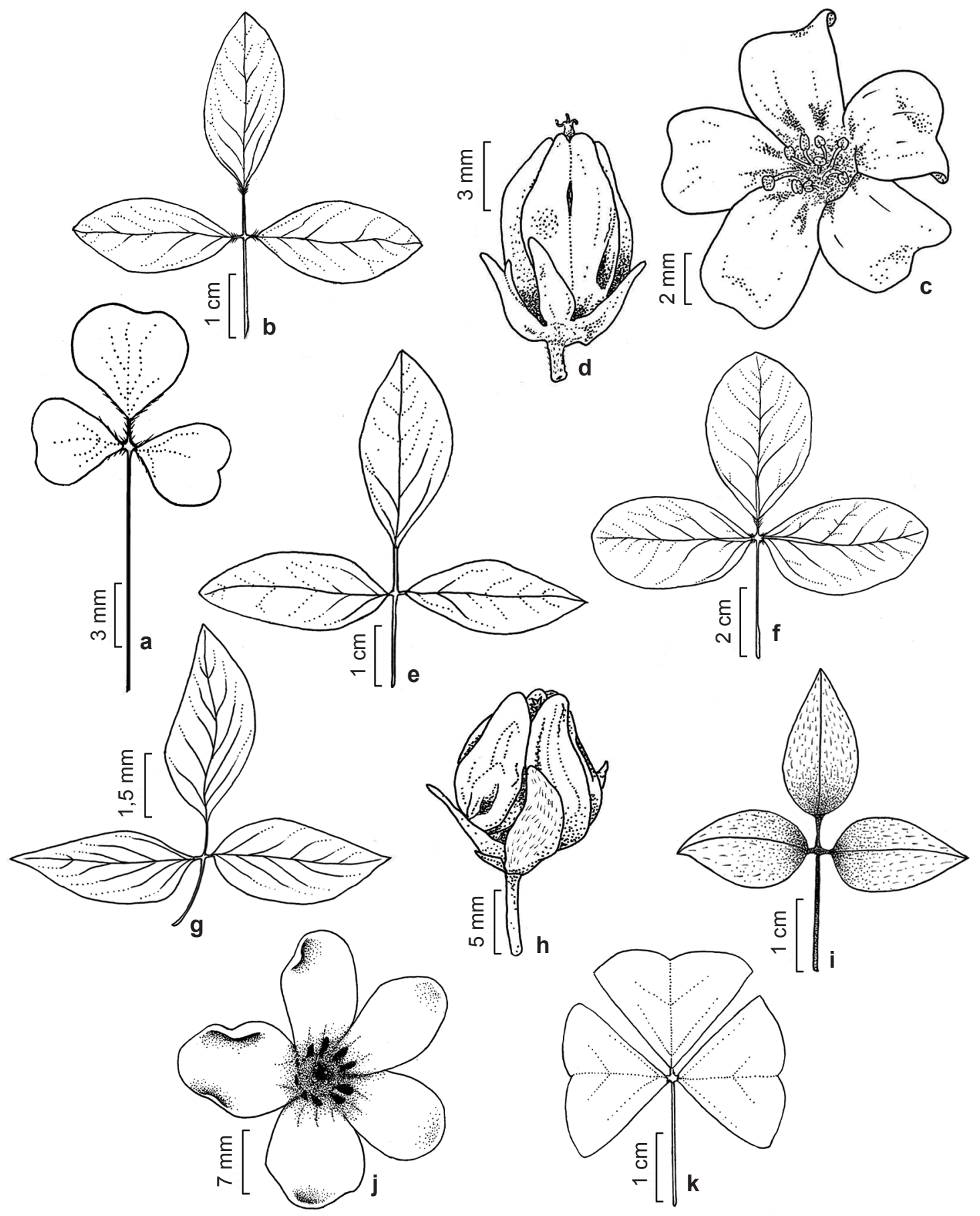

Figura 5 - a. Oxalis glaucescens - folha. b-d. O. grisea - b. folha; c. flor; d. fruto. e. O. hedysarifolia - folha. f. O. juruensis - folha. g,h. O. psoraleoides - g. folha; h. flor fechada. i-j. O. puberula - i. folha; j. flor. k. O. triangularis - folha. (a. M.A. Figueiredo et al. 68; b-d. A. Fernandes et al. - EAC 27883; e. M.I.B. Loiola 1559; f. A.V. Vieira 16; g,h. L.W. Lima-Verde - EAC 25598; i,j. M.F. Landim 455; k. M.A. Figueiredo 18).

Figure 5 - a. Oxalis glaucescens - leaf. b-d. O. grisea - b. leaf. c. flower; d. fruit. e. O. hedysarifolia - leaf. f. O. juruensis - leaf. g-h. O. psoraleoides - g. leaf; h. closed flower. i-j. O. puberula - i. leaf; j. flower. k. O. triangularis - leaf. (a. M.A. Figueiredo et al. 68 ; b-d. A. Fernandes et al. - EAC 27883; e. M.I.B. Loiola 1559; f. A.V. Vieira 16; g,h. L.W. Lima-Verde - EAC 25598; i,j. M.F. Landim 455; k. M.A. Figueiredo 18). 
$\times$ 1,5-6 mm, ovadas ou elípticas, pubescentes na face externa, glabras na interna. Pétalas 5-9 $\mathrm{mm}$ compr., obovadas a espatuladas, amareloalaranjadas; unha 1-2 $\mathrm{mm}$ compr.; tubo $2-5 \mathrm{~mm}$ compr. Estames curtos 1-4,5 mm compr.; estames longos 4-7 mm compr., ligulados; anteras $0,5-1$ $\mathrm{mm}$ compr., ovoides. Androginóforo ausente. Ginóforo $0,5-1,5 \mathrm{~mm}$ compr. Ovário $1,3-2 \mathrm{~mm}$ compr., ovado, glabro a pubescente, 1 óvulo por lóculo, estiletes $0,5-5 \mathrm{~mm}$ compr., estigma subcapitado. Cápsula 7-8 × 5,5-6 mm, oblonga, pubescente, sem tricomas glandulares nas linhas de suturas entre os carpelos. Sementes $4 \times 2,5$ $\mathrm{mm}, 2-5$ por lóculo, ovoide a elipsoide, achatada dorsiventralmente, transversalmente estriadas, com fendas nas depressões entre as estrias.

Material selecionado: : Baturité, CE 115, 20.X.1979, fl. e fr., A.J. Castro \& E. Nunes (EAC 7175). Guaramiranga, Sítio Sinimbu, 11.II.2003, fl. e fr., A. Silveira \& R.F. Oliveira 736 (EAC). Maranguape, Pirapora, 27.VI.1981, fl. e fr., E. Nunes \& P. Martins (EAC 10499). Pacatuba, Serra da Aratanha, 2.I.1996, fl. e fr., L.W. Lima-Verde \& L.P. Félix (EAC 23874). Pacoti, Florestinha, 11.V.2005, fl., F.S. Cavalcante (EAC 35537). Ubajara, Planalto Cafundó, Pl. da Ibiapaba - PARNA, 22.I.1999, fl. e fr., A. Fernandes et al. (EAC 27883).

É facilmente confundida com Oxalis juruensis quanto aos tricomas esbranquiçados a amarelo-alaranjados nos ramos e cápsula oblonga. No entanto, $O$. grisea tem folíolo terminal com ápice geralmente assimétrico e cápsula sem tricomas glandulares nas linhas de sutura entre os carpelos; enquanto $O$. juruensis possui folha com ápice obtuso a arredondado e cápsula com tricomas glandulares nas linhas de sutura entre os carpelos. Ocorre no Brasil e Bolívia (Lourteig 1994). No território brasileiro foi registrada nas regiões Nordeste, Centro-Oeste e Sudeste (BFG 2015). No território cearense sua ocorrência está geralmente associada à ambientes de floresta ombrófila densa (Fig. 1, quadrículas C2, C6, D6). Coletada com flores e frutos durante o ano inteiro. Nome popular: velame-bravo.

10. Oxalis hedysarifolia Raddi, Mem. Soc. Ital. Mod. xviii. Fis. 401. $1820 . \quad$ Figs.1; 4d,e; 5e

Subarbusto ou arbusto $50-70 \mathrm{~cm}$ alt., caule aéreo, ereto. Ramos tomentosos; internós 1,2-2,5 $\mathrm{cm}$ compr. Folhas alternas, pinadas, glabras a pubescentes, não concentradas no ápice dos ramos; estípulas ausentes; pecíolo 2-3,6 cm compr., cilíndrico, pubescente; peciólulo 1-2 $\mathrm{mm}$ compr., cilíndrico, pubescente; raque foliar 2-6 mm compr., pubescente; folíolo terminal
1,5-3,8 $\times 0,8-1,6 \mathrm{~cm}$, trulado, ápice agudo, base obtusa, margem inteira; folíolos laterais $1-2,4 \times$ $0,5-1,2 \mathrm{~cm}$, semelhantes ao terminal. Cimeiras dicasiais, 6-12-floras; pedúnculo 4,8-6,9 cm compr., cilíndrico, pubescente; brácteas $1 \mathrm{~mm}$ compr., 1-2 por flor, ovadas, pubescentes. Flores tristílicas; pedicelo 3-4 mm compr., glabro. Sépalas 3-4,5 × 1-2 mm, ovado-elípticas, pubescentes na face externa, glabras na interna. Pétalas 9-12 mm compr., espatuladas, amarelas; unha 1-2 mm compr.; tubo 3-4 mm compr. Estames curtos 1,5-2 $\mathrm{mm}$ compr., estames longos $2,5-3,5 \mathrm{~mm}$ compr., ligulados; anteras ca. $0,5 \mathrm{~mm}$ compr., oblongas. Androginóforo ausente. Ginóforo 0,2-0,4 mm compr. Ovário $0,8-1,1 \mathrm{~mm}$ compr., obclavado, 5-anguloso, glabro; 3 óvulos por lóculo; estilete 2,5-3,2 mm compr.; estigma bilobado. Cápsula 7-8 $\times 4,5-5 \mathrm{~mm}$, globosa a elipsoide, glabra. Sementes $2 \times 1,5 \mathrm{~mm}, 3$ por lóculo, ovoides, achatadas dorsiventralmente, 8-costadas longitudinalmente, transversalmente estriadas, sem fendas nas depressões entre as estrias.

Material examinado: Belmonte, encosta da chapada do Araripe, 10.III.1997, fl., A. Fernandes (EAC 24700). Crato, Chapada do Araripe, 17.IX.1992, fl., L.P. Félix 5419 (EAC). Tianguá, 26.IV.2012, fl., M.I.B. Loiola 1559 (EAC).

Material adicional: BRASIL. PARAÍBA: Areial, Engenho Sipilho, 16.III.1975, fl, V.P. Barbosa 180 (RB).

Distingue-se das demais espécies por apresentar folíolo terminal trulado e frutos globosoelipsoides, com três sementes por lóculo. Foi registrada na Bolívia, Brasil e Paraguai (Lourteig 1994). No Brasil está distribuída em todas as regiões (BFG 2015). No entanto, no estado do Ceará esta espécie tem apenas dois registros em ambiente de savana na Chapada do Araripe (Fig. 1, quadrícula J5). Coletada com flores em fevereiro, março e setembro, e com frutos em fevereiro e março. Nome popular: trevo-azedo.

11. Oxalis juruensis Diels, Verh. Bot. Vereins Prov. Brandenburg 48: 173. 1907.

Figs. 1; $5 \mathrm{f}$

Arbusto $70-100 \mathrm{~cm}$ alt., caule aéreo, ereto. Ramos pubescentes; internós 1,5-4 cm. Folhas alternas, subopostas ou opostas, pinadas, glabra, não concentradas no ápice dos ramos; estípulas ausentes; pecíolo $1-4,5 \mathrm{~cm}$, canaliculado, pubescente; peciólulo ca. $1 \mathrm{~mm}$ compr., cilíndrico, pubescente a tomentoso; raque foliar 1,5-5 $\mathrm{mm}$ compr., pubescente; folíolo terminal 1,5-4 × 1-2,5 $\mathrm{cm}$, obovado a oblongo, ápice obtuso a arredondado, base aguda a arredondada, margem ciliada; folíolos laterais $0,7-3 \times 0,5-2 \mathrm{~cm}$, semelhantes ao terminal. 
Cimeiras dicasiais, 4-10-floras; pedúnculo 1,2-3,7 cm compr., cilíndrico, piloso; brácteas ca. $2 \mathrm{~mm}$ compr., 1-2 por flor, lineares, pilosas. Flores tristílicas; pedicelo 2-4 mm compr., pubescente. Sépalas $2-4 \times 1,5-5 \mathrm{~mm}$, ovadas ou elípticas, pubescentes na face externa, glabras na interna. Pétalas 5-8 $\mathrm{mm}$ compr., obovadas a espatuladas, amarelo-alaranjadas; unha 1-2 mm compr.; tubo 2-4 mm compr. Estames curtos 1-4 mm compr., estames longos 4-7 mm compr, ligulados; anteras 0,5-1 mm compr., ovoides. Androginóforo ausente. Ginóforo 0,5-1 mm compr. Ovário 1-2 $\mathrm{mm}$ compr., ovado, glanduloso-pubescente, 2-5 óvulos por lóculo; estilete $0,5-5$ glabro; estigma subcapitado. Cápsula 6-7 × 5-6 mm, ovoide a elipsoide, com tricomas glandulares nas linhas de sutura entre os carpelos. Semente ca. $3 \times 2,5$ $\mathrm{mm}, 2-5$ por lóculo, ovoide a elipsoide, achatada, costada, transversalmente estriada, com fendas nas depressões entre as estrias.

Material selecionado: Crateús, Serra das Almas, 25.II.2002, fl., F.S. Araújo 1288 (EAC). Ibiapina, 18.XII.2007, fl. e fr., A.A. Leopoldino 8 (UFRN, HUEFS, HUVA). Maranguape, Vale do Vento, 7.VIII.2004, fl. e fr., A.V. Vieira 16 (EAC). Pacoti, estrada para Guaramiranga, escada de acesso à torre da TIM, 14.III.2014, fl., L.M. Versieux 702 (UFRN). Viçosa do Ceará, Sítio Pará, 14.VI.1979, fl. e fr., A. Fernandes et al. (EAC 6500). Ubajara, PARNA-Ubajara, 2.VII.1978, fl. e fr., A. Fernandes \& F. Matos (EAC 3947).

Como já comentado anteriormente, esta espécie pode ser reconhecida pelas folhas com ápice obtuso a arredondado e cápsula com tricomas glandulares nas linhas de sutura entre os carpelos. Pode ser facilmente confundida com Oxalis grisea e as características que distinguem estas espécies já foram apresentadas anteriormente. Tem distribuição no Brasil, Bolívia, Guiana, Guiana Francesa, Peru, Suriname e Venezuela (Lourteig 1994). No território brasileiro foi registrada nas regiões Norte, Nordeste e Centro-Oeste (BFG 2015). No Ceará ocorre frequentemente associada a ambientes mais úmidos como floresta ombrófila densa (Fig. 1, quadrículas C1, C2, D6); no entanto, foi encontrada também no município de Crateús em floresta estacional decidual. Floresce e frutifica nos meses de junho, julho, agosto e dezembro. Nome popular: velame-bravo.

12. Oxalis psoraleoides Kunth Kunth, Nov.Gen. Sp. 5: 246. 1821 (1822).

Figs. $1 ; 5 \mathrm{~g}, \mathrm{~h}$

Arbusto $60-80 \mathrm{~cm}$ alt., caule aéreo, ereto. Ramos pubescentes a tomentosos; internós $0,6-3,5$ $\mathrm{cm}$ compr. Folhas alternas, pinadas, pubescentes a tomentosas, não concentradas no ápice dos ramos; estípulas ausentes; pecíolo 2,5-5,6 cm compr., cilíndrico, tomentoso; peciólulo 1-2 mm compr., cilíndrico, hirsuto; raque foliar $0,6-1,2 \mathrm{~cm}$, tomentosa; folíolo terminal 3,2-6,3 × 1,3-2,6 cm, elíptico, ápice agudo, base obtusa, margem inteira; folíolos laterais $2-5,4 \times 1-2,1 \mathrm{~cm}$, semelhantes ao terminal. Cimeiras dicasiais, 5-16-floras; pedúnculo $3,7-7,5 \mathrm{~cm}$ compr., canaliculado, tomentoso; brácteas 1-2 mm compr., 1-2 por flor, ovadas, seríceas. Flores tristílicas; pedicelo 3-5 mm compr., seríceo. Sépalas 2,5-4 × 6-9 $\mathrm{mm}$, ovadas, elípticas ou oblongas, seríceas na face externa, glabras na interna. Pétalas $6-10 \mathrm{~mm}$ compr., obovadas a espatuladas, amarelas; unha ca. $2 \mathrm{~mm}$; tubo 3-6 mm compr. Estames curtos 2-4,5 mm compr.; estames longos 6-7 mm compr.; anteras $0,5-1 \mathrm{~mm}$ compr., ovoides. Androginóforo 0,1-0,4 mm compr. Ginóforo 0,5-1,5 mm compr. Ovário 1,3-2 mm compr., ovoide, pubescente a glabro, 1 óvulo por lóculo; estilete $0,5-5 \mathrm{~mm}$ compr.; glabro a pubescente; estigma subcapitado. Cápsula 7-8 $\times 6 \mathrm{~mm}$, ovoide, glabra. Sementes $4 \times$ 2,5 $\mathrm{mm}, 1$ por lóculo, ovoide a elipsoide, achatada dorsiventralmente, com pontuações transversais, sem fendas nas depressões entre as estrias.

Material examinado: Crateús, Mambira, 22.V.1997, fl. e fr., L.W. Lima-Verde (EAC 25598). Meruoca, encosta da Serra da Meruoca, 8.II.2001, fl. e fr., A. Fernandes (EAC 30342).

Esta espécie é reconhecida por ser um arbusto com caule aéreo e ereto, com ramos e folhas pubescentes a tomentosos, pétalas amarelas e cápsula ovóide, com uma semente por lóculo. Tem registro na Argentina, Bolívia, Brasil e Paraguai (Lourteig 1994). No Brasil ocorre nas regiões Nordeste e Sudeste (BFG 2015). No estado do Ceará, a ocorrência desta espécie está associada à floresta estacional decidual (Fig. 1, quadículas C3, F2). Floresce em janeiro, fevereiro, abril e maio, frutifica em fevereiro e maio. Nome popular: velame-vultoso, velame-bravo.

13. Oxalis puberula Nees \& Mart., Nova Acta Phys.-Med. Acad. Caes. Leop.-Carol. Nat. Cur. 12(1): 43.1824.

Fig. $1 ; 5 i, j$

Erva ou subarbusto $20-50 \mathrm{~cm}$ alt., caule aéreo, ereto. Ramos pubescentes; internós ca. 0,1 $\mathrm{mm}$ compr. Folhas alternas a pseudoverticiladas a alternas, pinadas, pubescentes, concentradas no ápice dos ramos; estípulas ausentes; pecíolo 3-6 cm compr., canaliculado, pubescente; peciólulo $1 \mathrm{~mm}$ compr., cilíndrico, piloso; raque foliar 6-15 mm, 
glabra; folíolo terminal 2-3 × 1-2 cm, elíptico, base obtusa a arredondada, ápice agudo, margem inteira; folíolos laterais $1-2,5 \times 0,5-1 \mathrm{~cm}$, semelhantes ao terminal. Cimeiras dicasiais, 4-9-floras; pedúnculo 1,3-3,6 cm compr., anguloso, viloso; brácteas não observadas. Flores tristílicas; pedicelo 3-5 $\mathrm{mm}$ compr., seríceo. Sépalas ca. 4-6 × $1 \mathrm{~mm}$, lanceoladas, vilosas. Pétalas 6-7 mm compr., obovadas, amarelas; demais estruturas não observadas.

Material examinado: em local não determinado, serra de Baturité, sítio B. Inácio de Azevedo, 9.XII.1939, veg., J.E. Leite 1302 (RB).

Material adicional: BRASIL. ALAGOAS: Arapiraca, mata de bananeiras, 8.VIII.1980, fl., grupo flora Pedra do Cavalo 298 (HUEFS, RB). ESPÍRITO SANTOS: Linhares, Rio Doce, fazenda de santa Adelaide, 5.XII.1943, fl., J.G. Kuhlmann 6625 (RB). MINAS GERAIS: sem município, serra de Antônio Pereira, 22.II.1883, fl., Glaziou 14586 (P). SERGIPE: Santa Luzia do Itanhy, mata do Castro, 5.VII.1995, fl., M.F. Landim 455 (ASE, EAC).

Caracteriza-se por ter caule ereto, ramos pubescentes, folhas alternas a pseudoverticiladas, concentradas no ápice dos ramos. Tem distribuição restrita ao Brasil e foi registrada nas regiões Nordeste e Sudeste (BFG 2015). No Ceará esta espécie tem ocorrência rara e tem-se o registro de apenas uma coleta na serra de Baturité em floresta ombrófila densa (Fig. 1D6). Nome popular: azedinha.

14. Oxalis triangularis A.St-Hil., Fl. bras. Mer. (quarto ed.) 1(3): 102. 1825. Figs. 1; 4f; 5k

Erva 15-25 cm alt.; caule subterrâneo, bulboso. Bulbos 3-6 cm compr., alongados rizomatosos; estolões presentes, produzindo bulbilhos secundários; bulbos escamosos, escamas externas 6-8 × 3-5 mm, membranáceas, ovadoarredondadas, 3-nervadas, escamas internas não observadas. Folhas alternas, digitadas, pubescentes, não concentradas no ápice dos ramos; estípulas ausentes; pecíolo 5-20 cm compr., cilíndrico, glabro; peciólulo ca. $1 \mathrm{~mm}$ compr., cilíndrico, viloso; raque foliar 1-1,2 $\mathrm{mm}$, glabra; folíolo terminal 2,1-2,3 × 3,2-3,6 cm, obtriangular, ápice retuso, base obtusa, margem inteira; folíolos laterais 1,9-2 × 3-3,3 cm, semelhantes ao terminal. Cimeiras umbeliformes, 3-18-floras; pedúnculo 7-19 cm compr., cilíndrico, glabro; brácteas ca. $2 \mathrm{~mm}$ compr., 1-2 por flor, ovadas a lineares, glabras. Flores tristílicas; pedicelo $0,8-2,5 \mathrm{~cm}$ compr., glabro. Sépalas 6-7 × 1,3-1,5 mm, lanceoladas, com duas calosidades alaranjadas no ápice, glabras, esverdeadas. Pétalas 1,4-2,2 cm compr., espatuladas, róseas com o centro esbranquiçado; unha 1-3 mm compr.; tubo 3-4 mm compr. Estames curtos 1,5-3,5 mm compr.; estames longos 4-6 mm compr.; anteras 0,5-0,7 $\mathrm{mm}$ compr., oblongas. Androginóforo ausente. Ginóforo 0,2-0,7 mm compr. Ovário 0,7-1 mm compr., obclavado, glabro; 6-10 óvulos por lóculo; estilete 1,5-4,5 mm compr.; estigma capitado a bilobado. Cápsula $1-1,5 \times 0,2-0,5 \mathrm{~cm}$, cilíndricoelipsoide, glabra. Sementes ca. 1,5 × 0,8 mm, 5-10 por lóculo, elipsoides, achatadas dorsiventralmente, longitudinal e transversalmente estriadas, sem fendas nas depressões entre as estrias.

Material examinado: Aiuaba, ESEC de Aiuaba, Lagoa do Rosio, 21.III.1991, fl., M.A. Figueiredo 18 (EAC). Capistrano, Fazenda Araçanga, 27.IV.1994, veg., L.B.L.P. Medeiros (EAC 21629). Santa Quitéria, Fazenda Itataia, 27.IV.1984, fl., A. Fernandes et al. (EAC 12528); Sobral, Fazenda Salgado, 22.II.1945, fl., Avelino \& Black (EAC 695). Ubajara, descida para Araticum, 21.I.1999, fl., E. Nunes et al. (EAC 27878).

É facilmente reconhecida pelas folhas digitadas, folíolos obtriangulares, bulbos alongados com estolões, sépalas lanceoladas com duas calosidades alaranjadas no ápice e pétalas roséas com o centro esbranquicado. Tem registro na Bolívia, Brasil, Paraguai e Argentina (Lourteig 1994). No Brasil não tem registro apenas na região Norte do país (BFG 2015). No território cearense foi encontrada na floresta ombrófila densa e na savana estépica/caatinga (Fig. 1, quadrículas C2, C3, D3, D6, I3). Floresce entre os meses de janeiro a abril. Nome popular: trevo, azedinha.

\section{Agradecimentos}

Ao CNPq, as bolsas de Iniciação Científica concedidas; à FUNCAP, o auxílio na compra de equipamentos para a realização deste trabalho; aos projetos INCT - Herbário Virtual da Flora e Fungos do Brasil (573.883/2008-4), Rede Integrada em Taxonomia de Plantas e Fungos - Sisbiota Brasil (563.342/2010-2), Efetividade de UCs Federais do estado do Ceará na conservação biológica do semiárido brasileiro - Ubajara e Aiuaba (551998/2011-3) e Estrutura e funcionamento de comunidades e populações do semiárido brasileiro (552213/2011-0), o apoio financeiro para as expedições de campo; a Guilherme Rodrigues e Naiana de Sousa Rodrigues, a confecção das pranchas ilustrativas. Maria Iracema Bezerra Loiola agradece ao CNPq a bolsa de pesquisador concedida. 


\section{Referências}

Abreu MC, Carvalho R \& Sales MF (2008) Oxalis L. (Oxalidaceae) no estado de Pernambuco, Brasil. Acta Botanica Brasilica 22: 399-416.

Abreu MC \& Fiaschi P (2009) Oxalidaceae. In: Stehmann JR, Forzza RC, Sobral M, Salino A \& Kamino LHY (eds.) Plantas de floresta Atlântica. Jardim Botânico do Rio de Janeiro. Disponível em $<\mathrm{http}$ / www.icb.ufmg.br.bot.mataatlântica $>$. Acesso em 13 setembro 2016.

Abreu MC \& Sales MF (2009) Oxalidaceae. In: Alves M, Araújo MF, Maciel JR \& Martins S (eds.) Flora de Mirindiba. Associação Plantas do Nordeste, Recife. Pp. 275-277.

Araújo FS, Costa RC, Lima JR, Vasconcelos SF, Girão LC, Sobrinho MS, Bruno MMA, Souza SSG, Nunes EP, Figueiredo MA, Lima-Verde LW \& Loiola MIB (2011) Floristics and life-forms along a topographic gradiente, central-wester Ceará, Brazil. Rodriguésia 62: 341-366.

Barbosa MRV, Sothers C, Mayo S, Gamarra-Rojas CFL \& Mesquita AC (2006) Oxalidaceae. In: Barbosa MRV, Sothers C, Mayo S, Gamarra-Rojas CFL \& Mesquita AC (eds.) Checklist das plantas do Nordeste brasileiro: angiospermas e gymnospermas. Ministério de Ciência e Tecnologia, Brasília. Pp. 156.

BFG - The Brazil Flora Group (2015) Growing knowledge: an overview of seed plant diversity in Brazil. Rodriguésia 66: 1085-1113.

Cocucci AA (2004) Oxalidaceae. In: Kubitzki K (ed.) The families and genera of vascular plants. Vol. 6 . Springer Verlag, Berlin, Heidelberg. Pp. 285-290.

Conceição AA \& Giulietti AM (1998) Flora da Serra do Cipó, Minas Gerais: Oxalidaceae. Boletim de Botânica da Universidade de São Paulo 17: 115-122.

Conceição AA \& Giullietti AM (2004) Flora de GrãoMogol, Minas Gerais: Oxalidaceae. Boletim de Botânica da Universidade de São Paulo 22: 385-387.

Conceição AA (2009) Oxalidaceae. In: Giulietti AM, Rapini A, Andrade MJG, Queiroz LP \& Silva JM (orgs.) Plantas raras do Brasil. Vol. 1. Conservação Internacional, Feira de Santana. Pp. 312-313.

Corrêa MP (1984) Dicionário das plantas úteis do Brasil e das exóticas cutivadas. $2^{\text {a }}$ ed. Imprensa Nacional, Rio de Janeiro. 745p.

Costa-Lima JL \& Alves M (2013) Oxalidaceae. In: Prata APN, Amaral MCE, Farias MCV \& Alves MV (orgs.) Flora de Sergipe. Triunfo, Aracaju. Pp. 491-499.

Daly DC \& Silveira M (2008) Oxalidaceae. In: Daly DC \& Silveira M (orgs.) Primeiro catálogo da flora do Acre. EDUFAC, Rio Branco. Pp. 291.

Donadio LC, Silva JAA, Araújo PSR \& Prado RM (2001) Caramboleira (Averrhoa carambola L.). Sociedade Brasileira de Fruticultura, Campinas. 81p.

Eiten G (1963) Taxonomy and regional variation of Oxalis section Corniculatae. I. Introduction, keys and synopsis of the species. The American Midland Naturalist 69: 257-309.

Fiaschi P (2010) Neotropical Oxalidaceae. In: Milliken W, Klitgård B \& Baracat A (eds.) Neotropikey - interactive key and information resources for flowering plants of the Neotropics. Disponível em <http://www.kew.org/science/tropamerica/ neotropikey/ families/Oxalidaceae.htm>. Acesso em 13 outubro 2016.

Fiaschi P \& Conceição AA (2005) Oxalidaceae. In: Wanderley MGL et al. (eds.) Flora fanerogâmica do estado de São Paulo. RiMa, São Paulo. Vol. 4, pp. 301-315.

Grigoletto D, Bertuzzi T, Eisinger SM, Canto-Dorow TS \& Colusso CS (2014) O gênero Oxalis L. (Oxalidaceae) no Rio Grande do Sul, Brasil. Ciência \& Natura 36: 594-612.

Gonçalves EG \& Lorenzi H (2011) Morfologia vegetal: organografia e dicionário ilustrado de morfologia das plantas vasculares. $2^{\text {a }}$ ed. Instituto Plantarum, São Paulo. 544p.

IBGE - Instituto Brasileiro de Geografia e Estatística (2012) Manual técnico da vegetação brasileira. $2^{\mathrm{a}}$ ed. Disponível em <ftp://geoftp.ibge.gov.br/ documentos/recursos_naturais/manuais_tecnicos/ manual_tecnico_vegetacao_brasileira.pdf $>$. Acesso em 16 novembro 2016.

IPNI - The International Plant Names Index (2016) The International Plant Names Index. The Royal Botanic Gardens, Kew. Disponível em <http://www.ipni. org > . Acesso em 20 novembro 2016.

Kissmann KG \& Groth D (2000) Plantas infestantes e nocivas. Tomo III. $2^{\text {a }}$ ed. BASF, São Paulo. Pp. 248-260.

Knuth R (1930) Oxalidaceae. In: Engler A (ed.). Das Pflanzenreich Regni Vegetabilis Conspectus. Vol. 130. Weinheim/Bergstrasse, W. Engelmann, Leipzig. Pp. 1-481.

Lemos RPL, Mota MCS, Chagas ECO \& Silva FC (orgs.) Checklist flora de Alagoas: angiospermas. Instituto do Meio Ambiente de Alagoas, Maceió. 141p.

Loiola MIB, Araújo FS, Lima-Verde LW, Souza SSG, Matias LQ, Menezes MOT, Silva MAP, Souza MMA, Mendonça ACAM, Macedo MS, Oliveira SF, Sousa RS, Balcázard AL, Crepaldi CG, Campos LZO, Nascimento LGS, Cavalcanti MCBT, Oliveira RD, Silva TC \& Albuquerque UP (2015) Flora da Chapada do Araripe. In: Albuquerque UP \& Meiado MV (orgs.) Sociobiodiversidade na Chapada do Araripe. Vol. 1. NUPEEA, Recife. Pp. 103-148.

Lourteig A (1980) Oxalidaceae extra-austroamericanae III. Oxalis L. subgenus Monoxalis Lourteig. Phytologia 46: 451-459.

Lourteig A (1983) Oxalidaceae. In: Reitz R (ed.) Flora Ilustrada Catarinense. Parte I, fasc. Oxal. Herbário Barbosa Rodrigues, Itajaí. Pp. 1-176.

Lourteig A (1994) Oxalis L. subgénero Thamnoxys (Endl.) Reiche emend. Lourt. Bradea 7: 1- 199. 
Lourteig A (2000) Oxalis L. subgéneros Monoxalis (Small) Lourt., Oxalis y Trifidus Lourt. Bradea 7: 202-629.

Menezes MOT, Taylor NP \& Loiola MIB (2013) Flora do Ceará, Brasil: Cactaceae. Rodriguésia 64: 757-774.

Nunes-Vidal WN, Vidal MRR, Almeida EC \& Vieira MF (1987) Flora of Viçosa. Oxalidaceae. Experientiae 30: 13-24.

Oberlander KC, Dreyer LL \& Bellstedt DU (2011) Molecular phylogenetics and origins of southern African Oxalis. Taxon 60: 1667-1677.

Radford AE, Dickson WC, Massey JR \& Bell CR (1974) Vascular plant systematics. Harper \& Row, New York. 891p.
Ribeiro-Silva S, Medeiros MB, Gomes BM, Seixas ENC \& Silva MAP (2012) Angiospermas from the Araripe Nacional Forest, Ceará, Brazil. Check List 8: 744-751.

Stevens PF (2001) Angiosperm Phylogeny Website: Oxalidales. Disponível em <http://www.mobot. org/MOBOT/research/APweb/>. Acesso em 14 março 2017.

Thiers B [continuamente atualizado] Index herbariorum: a global directory of public herbaria and associated staff. New York Botanical Garden's Virtual Herbarium. Disponível em $<$ http:// sweetgum.nybg.org/ih/>. Acesso em 11 dezembro 2016. 